DOI: https://doi.org/10.34069/AI/2021.48.12.25

How to Cite:

Ovcharenko, N., Merezhko, Y., Moskva, O., Neboga,O., Kosiak, L. (2021). Technological competence of future music teachers: diagnostic and formative methods. Amazonia Investiga, 10(48), 238-247. https://doi.org/10.34069/AI/2021.48.12.25

\title{
Technological competence of future music teachers: diagnostic and formative methods
}

\section{Технологічна компетентність майбутніх педагогів-музикантів: діагностувальна та формувальна методики}

Received: November 2, 2021

Accepted: December 12, 2021

\begin{abstract}
The study dwells upon the problem of technological competence of future music teachers, which is relevant to the current music and music-pedagogical education process in Ukraine and other countries. The objective of the article is to cover the results of the experimental research on methods of diagnosis and formation of future music teachers' technological competence. As a matter of fact, with the purpose of studying the problem, the following scientific research methods have been applied: a set of theoretical, diagnostic, mathematical statistics methods.

The essence of the concept of "technological competence" is revealed, which is an integral component of professional competence of a modern music teacher. The structure of the studied phenomenon is determined, which consists of the following components: axiological and cultural, epistemological and emotional; technological and operational; creative and professional. Moreover, the four groups of criteria are substantiated according:
\end{abstract}

\section{Резюме}

У статті розкрито проблему технологічної компетентності майбутніх педагогівмузикантів, яка є актуальною для музичної і музично-педагогічної освіти України та інших країн. Мета статті - висвітлення результатів експериментального дослідження методик діагностики i формування технологічної компетентності майбутніх педагогів-музикантів. Для дослідження означеної проблеми були застосовані наукові методи дослідження, як: комплекс методів теоретичні, діагностичні математичної сатистики. Виявлено сутність поняття «технологічна компетентність», яке $\epsilon$ невід'ємним компонентом професійної компетентності сучасного педагогамузиканта. Визначено структуру досліджуваного явища, яку складають компоненти: аксіологічно-культурологічний, гносеологічно-емоційний; технологічнодіяльнісний; творчо-професійний. Обгрунтовано чотири групи критеріїв: ціннісно-культурологічний, пізнавально-

\footnotetext{
${ }^{105}$ Doctor of Pedagogical Sciences, professor of the Department of Methods of Musical Education, Singing and Choir Conducting, Kryvyi Rih State Pedagogical University, Ukraine.

${ }^{106}$ Candidate of Pedagogical Sciences, associate-professor of the Department of Academic and Solo Vocal Institute Chairs, Borys Grinchenko Kyiv University, Kyiv, Ukraine.

${ }^{107}$ Doctor of Philosophy (PhD), Senior Lecturer at the Department of Pop Singing, Kyiv Municipal Academy of Music named after R. Glier, Ukraine.

${ }^{108}$ Candidate of art criticism, Lecturer at the Department of Pop Singing, Kyiv Municipal Academy of Music named after R. Glier, Ukraine.

${ }^{109}$ Candidate of Pedagogical Sciences, associate-professor of the Department of Methods of Musical Education, Singing and Choir Conducting, Kryvyi Rih State Pedagogical University, Ukraine.
} 
value-cultural,

cognitive-emotional, technological-operational and creativeprofessional. Finally, a diagnostic experiment was carried out, in the process of which special diagnostic methods were used of the formative experiment lies in the gradual formation of the technological culture of future teachersmusicians according to the developed author's technique, which includes four pedagogical conditions and a set of interrelated methods.

Keywords: diagnostic methods, formative methods, future music teacher, technological competence, the structure of technological competence.

\section{Introduction}

Currently, the main tasks of music and pedagogical education include the introduction of innovative technologies, the mastery and application of which should become a systemic process, covering various types of professional activities of music teachers. The implementation of such tasks requires a high level of technological competence of the teacher, which, in its turn, is one of the most significant, innovative and least developed components of the modern teacher's professional competence. Technological competence of future music teachers is based on their technological awareness, skills and abilities to apply innovative learning technologies for the formation of students' value orientations in the field of music, including the effectiveness of their general and musical abilities. Therefore, the research of modern scientists is characterised by great attention paid to the innovative learning technologies, technological knowledge and skills of students and teachers, as well as - teacher's technological competence. In particular, the works of scientists on the content of teachers' technological competence were important for substantiating the essence of future music teachers' technological competence (Dyachenko, 2013; Lola, 2003; Markova, 2015; Plutok, 2020); technological culture (Ostroverkhova, 2012; Rubtsova, 2009; Symonenko, 2001); essence and structure of pedagogical technology, considered in the general pedagogical direction (Sysoieva, 2011), in the didactic direction (YerastovaMykhalus, 2016; Piekhota, 2010; Selevko, 2005), from the standpoint of personal and creative influence of musical art (Labunets, 2014; Masol, 2015; Ovcharenko, Matveieva \& Chebotarenko, 2020); the essence of innovative technologies for future music teachers' training (Ovcharenko, Samoilenko, Moskva, \& емоційний, технологічно-діяльнісний, креативно-професійний. Здійснено діагностувальний експеримент, у процесі якого були застосовані спеціальні діагностувальні методи та - формувальний експеримент під час якого проходило поетапне формування технологічної культури майбутніх педагогів-музикантів за розробленою авторською методикою, яка включає чотири педагогічні умови та комплекс взаємопов'язаних методів.

Ключові слова: діагностувальна методика, майбутній педагог-музикант, структура технологічної компетентності, технологічна компетентність, формувальна методика.

Chebotarenko, 2020), the formation of an evaluative attitude to technology, the ability to implement effective technologies in the educational process; to arouse the interest of future teachers in the art of music by means of the latter (Moskva, 2021).

However, the analysis of scientific studies by foreign and domestic scientists showed that the problem of determining effective methods of diagnosis and development of future music teachers' technological competence has not been the subject of a separate scientific study so far. Therefore, the objective of the study is to cover the results in the experimental research on methods of diagnosis and development of technological competence with future music teachers.

\section{Theoretical Framework or Literature Review}

Regarding the problem of the study, the carried out theoretical analysis of modern scientific research of the concept interpretation of "technological competence" provided an opportunity to identify the main areas of the research with the modern scientists, in particular: O. Plutok believes that such a competence is "an intellectual and cognitive activity of the teacher represented in the form of deep interest and strong will to acquire knowledge about the innovative learning technologies accumulated in the educative space, expanding the personality's education, outlook, erudition and aimed at the long-term development of educational activities" (Plutok, 2020); L. Kuzemko presents this definition as "a logical combination of theoretical knowledge, ways of organizing the educational process in educational institutions and practical skills to apply the designed educational activity, 
to analyse and evaluate results" (Kuzemko, 2015); L. Tyshakova interprets this concept as "education that contains knowledge, technological skills, creative and technological abilities, technological reflection as well as professional qualities" (Tyshakova, 2005). Accordingly, L. Koval's opinion that technological competence is a structural and functional component of professional competence, characterized by the future specialist's ability to independently organize the educational process at school based on the use of general educational technologies should be considered relevant (Koval, 2012. The critical analysis of the mentioned above research allowed us to denote that the technological competence of the future teacher-musician is an integral component of professional competence of a modern teacher (both school and university teacher), a dynamic professional and personal education provided by a set of worldview values to artistic technological experience, technological knowledge and skills, determining the ability to master and apply music learning technologies in the educational process in order to provide musical and pedagogical activities effectively.

Consequently, in the process of theoretical research, the analysis of modern technologies of teaching music was carried out, which are classified as follows: technologies aimed at mastering the musical-performing and musicalmethodical bases; information and computer technologies in distance learning, in particular, aimed at teaching the art of music, mastering the basics of sound amplification equipment by future performers and music teachers; technologies that have a health focus. Thanks to the application of the classification method, it was possible for future music teachers to master the technologies of music education.

Based on the elucidation of the music teachers' activity functions, we have substantiated the structure of future music teachers' technological competence, consisting of the following components: axiological-cultural, epistemological-emotional; technological and operational; creative and professional.

Table 1.

Components of the structure, criteria and their indicators of the development of future music teachers' technological competence.

\begin{tabular}{|c|c|c|}
\hline Components & Criteria & Indicators \\
\hline $\begin{array}{l}\text { Axiological and } \\
\text { cultural }\end{array}$ & value-cultural & $\begin{array}{l}\text { - the degree of awareness of the value of the technological competence } \\
\text { development; } \\
\text { - the level of development of future music teachers' technological } \\
\text { worldview; } \\
\text { - the degree of ability to self-actualization in mastering the values of } \\
\text { technological competence. }\end{array}$ \\
\hline $\begin{array}{l}\text { Epistemological } \\
\text { and emotional }\end{array}$ & $\begin{array}{l}\text { cognitive- } \\
\text { emotional }\end{array}$ & $\begin{array}{l}\text { - the level of cognitive interest, needs and emotional focus on learning } \\
\text { the technologies of music education; } \\
\text { - the degree of formation of knowledge of basic music-technological } \\
\text { concepts and traditional and innovative technologies of music } \\
\text { education; } \\
\text { - the degree of formed ability to cognitive and emotional growth in the } \\
\text { process of mastering the technologies of music education. }\end{array}$ \\
\hline $\begin{array}{l}\text { Technological and } \\
\text { operational }\end{array}$ & $\begin{array}{l}\text { technological- } \\
\text { operational }\end{array}$ & $\begin{array}{l}\text { - the level of motivation to master the technological activities of the } \\
\text { teacher-musician; } \\
\text { - the degree of skills formation to apply optimally effective } \\
\text { technologies in music education; } \\
\text { - the degree of the developed ability to personal and operational } \\
\text { mobility in perception and use of technologies for music training. }\end{array}$ \\
\hline $\begin{array}{l}\text { Creative and } \\
\text { professional }\end{array}$ & $\begin{array}{l}\text { creative- } \\
\text { professional }\end{array}$ & $\begin{array}{l}\text { - the level of interest and need for professional creativity; } \\
\text { - the degree of formed ability to integrate elements of traditional } \\
\text { technologies, to vary the forms, methods and means of music } \\
\text { education and to create new technologies of such education; } \\
\text { - the level of creative activity and a positive attitude to technological } \\
\text { activities and focus on music and pedagogical self-education }\end{array}$ \\
\hline
\end{tabular}

There have also been substantiated four groups of criteria according to the components of the structure of future music teachers' technological competence: value-cultural, cognitive- emotional, technological-operational and creative-professional, as shown in (Table 1). 


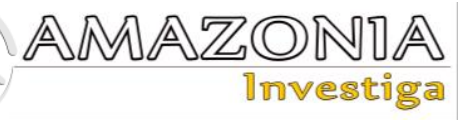

Methodology

As a matter of fact, with the purpose of studying the problem, the following scientific research methods have been applied:

- technological and competence approaches that helped to define the essence of the concept of "technological competence of the future music teacher"; analysis and classification of technologies for teaching music; clarifying the essence of technological knowledge, future music teachers' skills and the formation of abilities to apply technological knowledge and skills in the educational process; determining the content of the components in the structure of future music teachers' technological competence;

- a set of theoretical methods, such as analysis, systematization, comparison of different scientific views, concretization and generalization - to determine the essence of the basic concept of the research; classification - to identify the areas of technologicalization in the system of music and pedagogical education; systemstructural analysis - to substantiate the component structure of technological competence; modelling - in order to determine the criteria for assessing the development of technological competence with future teachers-musicians;

- a set of diagnostic methods: pedagogical observation, discussion, surveys, questionnaires, interviews, diagnostic tasks and maps, creative tasks, comparison, evaluation - to determine the levels of future music teachers' technological competence;

- formative experiment - to test the method of development of the phenomenon under study;

- mathematical statistics in order to determine, interpret and prove the reliability of the results in the pedagogical experiment.

\section{Results and Discussion}

In order to determine the effectiveness of diagnostic methods and the development of future music teachers' technological competence, the research work was conducted during 2018-2021 and included: diagnostic experiment - 2018 and formative experiment 2019-2021 on the basis of the Faculty of Arts in Kryvyi Rih State Pedagogical University and Kyiv Municipal Academy of Music named after R. Glier.
Initially, the diagnosis of the present level of technological competence of future music teachers was associated with the selection of already developed ones along with the creation of new author's methods for diagnosing components of the phenomenon structure. The number of students who participated in the diagnostic study was 74 people: 38 students of the experimental group (EG) and 36 students of the control group (CG).

To diagnose the axiological and cultural component of technological competence of future music teachers, M. Rokeach's method "Value Orientations" (Rokeach, 1973) was modified to determine students' opinion on the value of forming technological competence of music teachers; the author's questionnaire "Determination of the level of formation of the technological worldview and the degree of the future music teacher's self-actualization ability in mastering the values of technological culture" was developed.

Correspondingly, when diagnosing the epistemological and emotional component of technological competence of future music teachers, an author's questionnaire was developed to identify students' level of cognitive interest, needs and emotional focus on knowledge of music learning technologies and the degree of ability to cognitive and emotional growth in mastering them; a questionnaire "Determination of the degree of knowledge formation of basic music-technological concepts and technologies in music education" as well as a diagnostic task "Determination of the level of technological knowledge of the future teachermusician" were also elaborated.

Furthermore, the technological and activity component of technological competence of future music teachers was diagnosed by applying the test "Motivation of technological activity" by K. Zamfir, modified by A. Rean (1999) in the author's adaptation to identify the level of motivation to master the technological activities of teachers in music education; the author's diagnostic card "Assessment of technological skills of a music teacher" to identify students' opinions on their own level of skills to use optimally effective technologies of music education in the educational process and diagnostic tasks "Identification of technology skills of future music teachers" were also implemented at the stage; the author's test "Analysis and solution of musical and pedagogical cases" to identify the degree of formed ability to personal and operational 
mobility in the use of music learning technologies was still engaged.

Eventually, in order to diagnose the creative and professional component of technological competence of students, a questionnaire "Interest and need for professional creativity" was developed; certain creative tasks to identify the degree of existing ability to integrate elements of technology, to vary forms, methods and tools and create new technologies of music education were of great significance; the questionnaire "Readiness for technological self-education" to determine the level of creative activity and a positive attitude to technological activities and focus on music and pedagogical self-education was also applied.

According to the results of the pedagogical diagnosis, it was found that there are $16(44.45 \%)$ students in the control group (CG) and 16 $(42.10 \%)$ of the experimental group (EG) with a low level of technological culture, with the average level - $17(47.22 \%)$ students of CG and $18(47.37 \%)$ EG. Only $3(8.33 \%)$ students of CG and $4(10.53 \%)$ EG showed a high level.

In order to form the technological competence of future music teachers, a formative experiment was conducted during 2019-2021 with students of the experimental group (38 people) and provided a test of the effectiveness of the author's methodology, which is based on pedagogical conditions and a set of interrelated methods of music training (Table 2), the implementation of which provided a systematic mastery of music learning technologies according to the classification.

Table 2.

Pedagogical conditions and methods of development of future music teachers' technological competence.

\begin{tabular}{|c|c|}
\hline Pedagogical Conditions & Methods \\
\hline $\begin{array}{l}\text { Stimulating the students' } \\
\text { attitude to master the } \\
\text { values of technological } \\
\text { culture }\end{array}$ & $\begin{array}{l}\text { - actualization of the importance of the future music teacher's technological } \\
\text { competence; } \\
\text { - "surprise and admiration"; } \\
\text { - presentation of music and pedagogical technologies to arouse interest; } \\
\text { - popularization of the world experience of teachers-innovators; } \\
\text { - method of illustrations of forms, methods, means of music-pedagogical } \\
\text { technologies and elements of music education technologies; } \\
\text { - search tasks related to the history of music learning technologies; analysis and } \\
\text { comparison of technologies; } \\
\text { - creating a situation of professional success. } \\
\text { - conscious technological training; }\end{array}$ \\
\hline $\begin{array}{l}\text { Activation of cognitive and } \\
\text { emotional potential of } \\
\text { students' personality in the } \\
\text { knowledge of music and } \\
\text { pedagogical technologies }\end{array}$ & $\begin{array}{l}\text { - heuristic conversation to search, an ability to distinguish the important; } \\
\text { - classification of music learning technologies; } \\
\text { - comparison; } \\
\text { - method of the project "Technologies of music education"; } \\
\text { - method of suggestopedia auto training; }\end{array}$ \\
\hline $\begin{array}{l}\text { Algorithmizing the } \\
\text { technological activity of } \\
\text { future music art teachers }\end{array}$ & $\begin{array}{l}\text { - verbalization of technological solutions to the problem in music education. } \\
\text { - expediency and prospects in music-technological education; } \\
\text { - creation of an indicative basis for technological actions; } \\
\text { - operational-activity method; } \\
\text { - practical verification of the effectiveness of music learning technology; } \\
\text { - explanation of technological activities; } \\
\text { - training and exercises; } \\
\text { - reflections for understanding one's own musical-technological experience; } \\
\text { - blitz answers. }\end{array}$ \\
\hline $\begin{array}{l}\text { Purposefulness of gradual } \\
\text { development of students' } \\
\text { technological creativity }\end{array}$ & $\begin{array}{l}\text { - method of independent creative and analytical tasks; } \\
\text { - method of integrating different musical elements and pedagogical technologies; } \\
\text { - method of modelling the content, forms, methods, means of music and } \\
\text { pedagogical technology; } \\
\text { - method of creating music-pedagogical technology with forecasting the result of } \\
\text { the effectiveness of its implementation. }\end{array}$ \\
\hline
\end{tabular}

The gradual development of future music teachers' technological culture, according to the method we have substantiated, took place alternately at value-stimulating, cognitive, praxeological as well as creative stages and was carried out in classroom forms of learning: at individual lessons "Musical Instrument" and "Vocal Class", extracurricular activities and during pedagogical practice in institutions of specialized art education. 


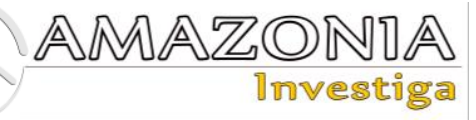

The value-stimulating stage provided for the formation of the axiological-cultural component of students' technological competence, due to the introduction of the first pedagogical condition and the corresponding value-stimulating methods. The tasks of the value-simulating stage were: instructing teachers on the essence of experimental work at this stage; enrichment of topics of musical instrument and vocal class, which acquainted students with the activities and technological functions of the teacher-musician, motivating them to master modern music education technologies, activation of students' attitudes to master the values of technological competence; conducting extracurricular forms - a master-class on the use of innovative technologies of music education conducted by innovative teachers, which contributed to the future music teachers' interest in music education technologies.

The cognitive stage was aimed at forming the epistemological and emotional component of technological competence of future music teachers through the introduction of the second pedagogical condition and suggestive-cognitive methods correspondingly. The tasks of the stage included: preliminary discussion with teachers of instrumental and vocal disciplines on the content of the experimental work at this stage; conducting a system of individual lessons on "Musical Instrument" and "Vocal Class", the introduction of extracurricular forms - methods of the project "Music Learning Technologies", which carried out the formation of students' cognitive interest, their needs and emotional focus on mastering music learning technologies; students' technological knowledge on basic concepts and traditional and innovative technologies of music education; development of students' ability to cognitive and emotional growth in the process of mastering the music education technologies.

The praxeological stage of the experiment had a practical orientation and provided for the development of technological and operational component of students' technological competence, due to the introduction of the third pedagogical condition and its corresponding methods. Among the most important tasks of the stage were: informing teachers about the essence of formative and experimental work at the praxeological stage; conducting a system of classes in instrumental and vocal disciplines, which motivated students to master the technological and practical activities of teachers in the course of music education; formation of technological skills to apply optimally effective technologies of music learning in the educational process and the ability to personal and activity mobility in the perception and use of music learning technologies; implementation of students' self-examination of the formed technological skills in the process of pedagogical practice in the institution of specialized art education.

The creative stage was aimed at forming a creative and professional component of future music teachers' technological competence through the introduction of the fourth pedagogical condition and creative methods meeting it. The tasks of the stage were: to conduct classes in instrumental and vocal disciplines, which intensified the students' interest and needs in professional creativity when applying music learning technologies; formation of the ability to integrate elements of traditional technologies, to vary the forms, methods and means of music education and to create new ones; stimulation of creative activity, setting a positive attitude to technological activities and focus on music and pedagogical self-education; creative approach to the application of music learning technologies in the process of pedagogical practice.

To sum up the results of the formative experiment, which consisted in testing the effectiveness of the method of developing the future music teachers' technological competence, the methods applied during the diagnostic experiment were used here. In the study, we proceeded from the position that the formation of technological competence is understood as a combination of high and medium levels of this phenomenon, an unformed one corresponds to the low level of technological competence of future music teachers.

According to the results of the formative experiment it was found that there are 12 (33.33\%) students of the control group (CG) and $4(10.53 \%)$ of the experimental group (EG) with a low level of technological competence, with the average level - $20(55,56 \%)$ students of CG and $22(57.89 \%)$ in EG. A high level was shown by $12(31.58 \%)$ students of $\mathrm{CG}$ and $4(11.11 \%)$ students in EG.

Comparing the results of the two groups after the formative experiment, we estimate that the level of formation of technological competence of future music teachers of EG has increased significantly compared to students in CG. The same characteristic corresponds to the high level. We also note significant differences in the low 
level, which is much lower in EG students than in CG students.

The next stage of our study was a comparative analysis of the levels of formation of future music teachers' technological competence according to the results of the diagnostic and formative experiments.

The diagnostic experiment showed that the levels of technological competence formation with future music teachers of the experimental and control groups hardly ever differ. According to the results of the formative experiment, the calculations made revealed an increase in the dynamics of increasing the levels of technological competence in both groups. However, the level of technological competence formation of future teachers-musicians in EG is much higher than that of students' in CG. Figure 1 shows the difference at the beginning (diagnostic) and at the end (formative) of the experiment between the levels of formation among the students in the experimental and control groups.

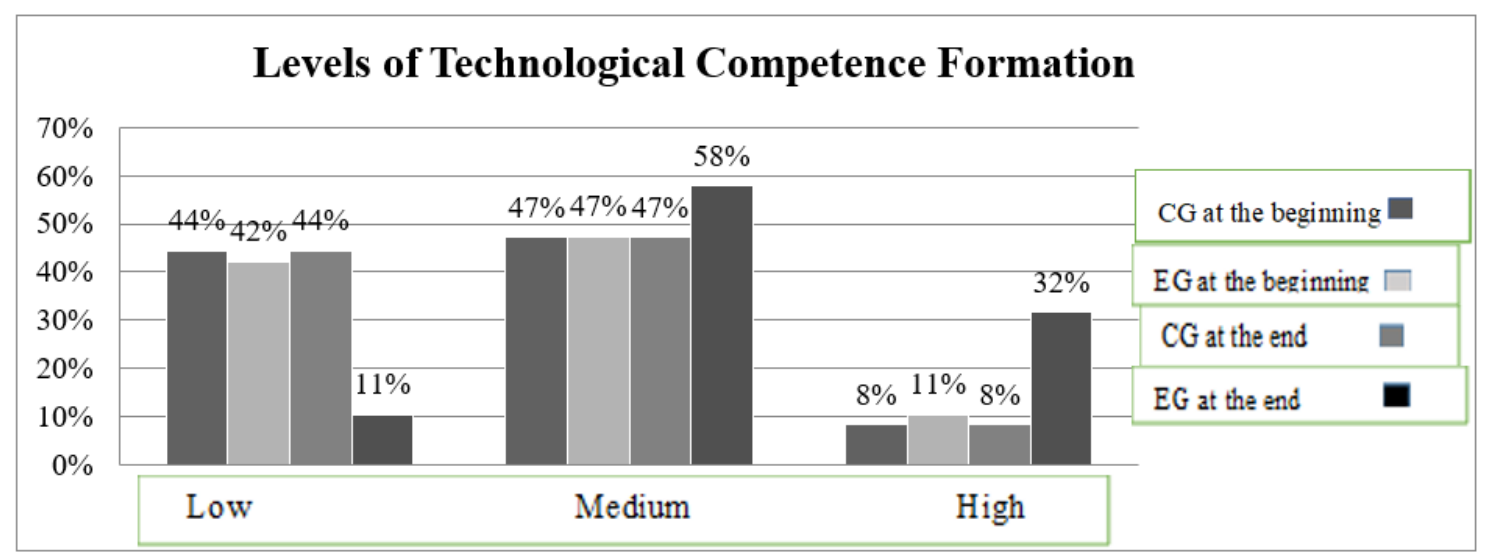

Figure 1. Levels of technological competence formation in the experimental group (EG) and control group (CG) at the beginning (diagnostic section) and at the end (formative section) of the experiment.

The method of mathematical data processing helped to determine that in EG the group of students with a high level, the technological competence increased by $21.05 \%$, while in the control group - by $2.78 \%$. Regarding the average (medium) level of this phenomenon formation, the number of future teachers-musicians in EG increased by $10.52 \%$, in the control group - by $8.34 \%$. With a low level of technological competence formation in EG, the group of students decreased by $31.57 \%$, in the control group - by $11.12 \%$. That is, the experiment revealed that the level of formation of technological competence has increased significantly among future music teachers from EG in comparison with CG (Fig. 2).

Thus, the value of the difference between indicators in EG and CG by the results of the diagnostic experiment and formative experiment can be proved through applying Fisher's statistical test, as: the number of students from the two groups of EG and CG participating in the formative experiment was more than 5 people, currently there are 38 EG students and 36 future music teachers in CG.
To test the statistical hypotheses, the following hypotheses were outlined, such as: $\mathrm{H}_{0}$ : the formation of the component in the first sample, the share of individuals should not be higher than the share of the second sample. $\mathrm{H}_{1}$ : the formation of the component in the first sample, the share of individuals should be significantly different compared to the share of the second sample.

The calculations took into account the limitations associated with the application of the multifunctional Fisher's test, namely: both compared shares should not equal zero; to compare the number of observations for the two samples should be more than five; for the criterion, there is no upper limit on the number of observations in the two samples.

Zero $\left(\mathrm{H}_{0}\right)$ and alternative hypotheses $\left(\mathrm{H}_{1}\right)$ are to be formulated:

$\mathrm{H}_{0}$ : the share of persons who show the studied effect in the first sample is not greater than in the second sample;

$\mathrm{H}_{1}$ : the share of persons who show the studied effect in the first sample differs significantly from the share in the second sample. 


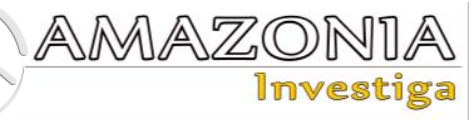

The calculations of the empirical value of the criterion $\varphi$ emp were performed according to the formula:

$$
\varphi_{\text {емп }}=\left|\varphi_{1}-\varphi_{2}\right| \cdot \sqrt{\frac{n_{1} \cdot n_{2}}{n_{1}+n_{2}}}
$$

where $n_{1}$ is the number of observations in the first sample, $n_{2}$ is the number of observations in the second sample; $\varphi_{1}=2 \cdot \arcsin \left(\sqrt{p_{1}}\right)$ the value corresponding to the percentage $\mathrm{p} 1$ of the first sample, $\varphi_{2}=2 \cdot \arcsin \left(\sqrt{p_{2}}\right)$ - the value corresponding to the percentage $\mathrm{p} 2$ of the second sample.

Hence, the calculations of the empirical value of the criterion $\varphi$ emp according to the results of the diagnostic experiment by formula (1), taking into account the shares of the sum of medium and high levels $\mathrm{p} 1=0.56$ for the first sample (control group) and $\mathrm{p} 2=0.58$ for the second sample (experimental group) led to calculating $\varphi$ emp $=$ 0.20 , which is less than the critical value of $\varphi 0.05$ $=1.64$. This means that there is no reason to reject the null hypothesis: the sum of medium and high levels of technological competence of the $\mathrm{CG}$ at the beginning of the experiment does not differ from the same EG at the diagnostic stage of the experiment.

Then we calculated the empirical value of the criterion $\varphi$ emp at the end of the experiment and obtained $\varphi_{-}$emp $=2.45$, which exceeds the critical value of 1.64 . This means that the null hypothesis must be rejected: the sum of medium and high levels of technological culture formation of future music teachers in CG at the end of the experiment is significantly lower than the same EG indicator at the end of the experiment.

In addition, a study was conducted that during the experiment in the experimental group the share of high level significantly increased from 0.11 to 0.32 .

$\varphi \_$emp $=0.32<\varphi \_$crit $=1.64$ when comparing high-level shares for CG and EG at the beginning of the experiment indicates that high-level shares at the diagnostic stage of the experiment do not differ significantly.

$\varphi \_$emp $=2.21$ exceeds the critical value when processing the results of the formative stage of the experiment. That is, the share of high level in the experimental group at the end of the experiment is significantly higher than in the control one.

Thus, in the experimental group during the experiment on the formation of technological competence of future music teachers, the following probability has been statistically confirmed: an increase in the share of the sum of the medium with high levels; reduction of the share of low level; increase in the share of high level of formation of technological culture of future music art teachers. In the control group, the proportions of values by levels at the diagnostic and formative stages of the experiment do not differ significantly.

Table 3.

Dynamics of technological competence formation of future music teachers.

\begin{tabular}{|c|c|c|c|c|c|c|}
\hline \multirow[b]{2}{*}{ Levels of readiness } & \multicolumn{2}{|c|}{$\begin{array}{l}\text { Quantitative } \\
\text { indicators }\end{array}$} & \multirow{2}{*}{$\begin{array}{l}\text { Change } \\
\text { Indicator }\end{array}$} & \multicolumn{2}{|c|}{ Quantitative indicators } & \multirow{2}{*}{$\begin{array}{l}\text { Change } \\
\text { Indicator }\end{array}$} \\
\hline & \multicolumn{2}{|c|}{$\begin{array}{l}\text { at the beginning of } \\
\text { the experiment }\end{array}$} & & \multicolumn{2}{|c|}{$\begin{array}{l}\text { at the end of } \\
\text { the experiment }\end{array}$} & \\
\hline Low & 0,421 & 0,444 & $-0,023$ & 0,105 & 0,333 & $-0,228$ \\
\hline Medium/Average & 0,474 & 0,472 & 0,002 & 0,579 & 0,556 & 0,023 \\
\hline High & 0,105 & 0,083 & 0,022 & 0,316 & 0,111 & 0,205 \\
\hline
\end{tabular}

In particular, the comparison of the sum shares of the high and medium levels, i.e. the "formation" of technological competence of future teachers of music EG and $\mathrm{KG}$ at the beginning (according to the results of diagnostic) and at the end (according to the results of formative) experiment is shown in Fig. 2. 


\section{Comparison of Sum Shares for Higt and Medium Levels}

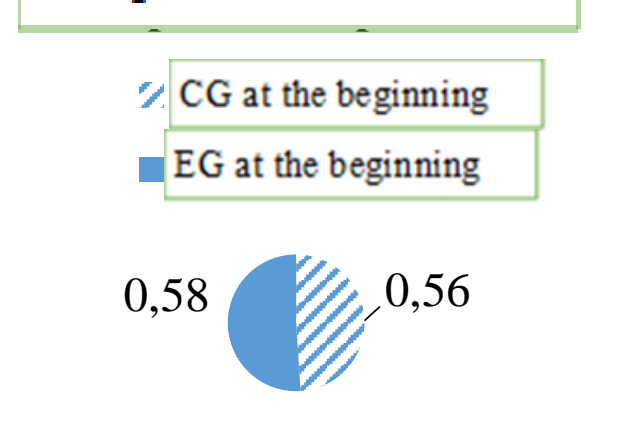

\section{Comparison of Sum Shares for Higt and Medium Levels}

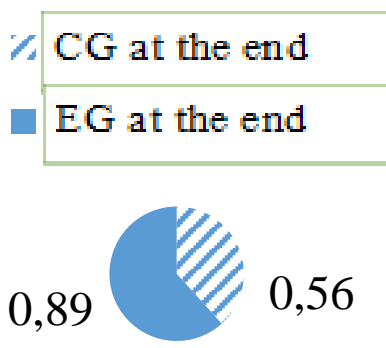

Figure. 2. Determining the share of the high and medium levels sums for CG and EG at the beginning and end of the experiment on the technological competence formation of future music teachers.

Unoubtedly, the study made it possible to prove the effectiveness of diagnostic and formative methods of the technological competence formation with future music teachers.

\section{Conclusions}

Thus, the urgency of the problem on forming technological competence of future music teachers is caused by the common need in most countries to modernize music education in general, which requires the use of world technological experience in the process of students' music education by modern teachers in terms of specialized art institutions, in particular. The music teacher must be competent and be able to skilfully apply innovative learning technologies to form the students' value orientations in the field of music, to maximize the effectiveness of their students' general musical abilities and increase children's interest in learning the art of music. The results of the theoretical research allowed us to substantiate the essence of the basic concept of "technological competence", which is an integral component of professional competence of a modern music teacher, a dynamic professional and personal educational phenomenon, provided by a set of worldview values in music technology experience, technological knowledge and skills which, in their turn, determine the ability to master, implement music learning technologies in the educational process in order to apply them effectively in the musical and pedagogical activities. Consequently, we can distinguish the structure of the phenomenon under study, which consists of such components as: axiological and cultural, epistemological and emotional; technological and operational; creative and professional along with four groups of criteria according to the components of the structure of future music art teachers' technological competence: value-cultural, cognitiveemotional, technological-operational and creative-professional. In order to determine the current level of technological competence of future teachers-musicians in terms of higher music and music-pedagogical education, a diagnostic experiment was conducted, in the process of which special diagnostic methods were used, such as questionnaires, tests, diagnostic cards, creative tasks, etc. The structure of the formative experiment lies in the gradual formation of the technological culture of future teachers-musicians according to the developed author's technique, which includes four pedagogical conditions and a set of interconnected methods, the implementation of which took place alternately in valuestimulating, cognitive, praxeological and creative stages correspondingly. So, the study proved the high efficiency of the diagnostic and formative methods in forming the technological competence of future music teachers.

\section{Bibliographic references}

Dyachenko, A. (2013). Theoretical analysis of the concept of "technological competence of the teacher". Problems of modern teacher's training, 8(2), 53-59. URL: https://library.udpu.edu.ua/library_files/prob 1_sych_vchutela/2014/8_2/8.pdf.

Koval, L.V. (2012). Professional training of the future teachers in the context of the development of the primary education. Donetsk: LANDON-XXI. URL: http://surl.li/bdbra

Kuzemko, L.V. (2015). Content, forms, methods of formation of technological competence of students of pedagogical specialties. Educational Discourse, 2 (10), 159 - 169. 


\section{AMAZOND凨}

Labunets, V.M. (2014). Innovative technologies of instrumental and performance training of future music teachers: theory and methods. Kamianets-Podilskyi: Publisher PE Zvoleiko D.G. [In Russian]

Markova, S.M. (2015). Technological competence of the teacher of professional training. Modern research of social problems, 3(47), 30-31. [In Russian]

Masol, L. M. (2015). Art and pedagogical technologies in primary school: the unity of teaching and education. Kharkiv: Drukarnia Madryd. [in ukrainian]

Moskva, O.M. (2021). Formation of technological culture of future teachers of music art in the process of vocal training (PhD in Philosophy Sciences Thesis) Secondary education (Music art)". South Ukrainian National Pedagogical University named after K.D. Ushynsky. Odessa. URL: https://pdpu.edu.ua/doc/vr/2020/moskva/dis. pdf

Ovcharenko, N., Matveieva, O., \& Chebotarenko, O. (2020). Metodological readiness formation of future music art teachers for their professional activity. Amazonia Investiga, 9(27), 157 - 164. DOI: http://dx.doi.org/10.34069/AI/2020.27.03.16

Ovcharenko, N., Samoilenko, O., Moskva O., \& Chebotarenko, O. (2020). Innovative Technologies in Vocal Training: Technological Culture Formation of Future Musical Art Teachers. Journal of History Culture and Art Research, 9 (3), 115-126. doi: http://dx.doi.org/10.7596/taksad.v9i3.2729

Ostroverkhova, N.M. (2012). Methodology of formation of technological culture of a general educational institution head. Kyiv: Pechatna Dumka. [in ukrainian]

Piekhota, O.M. (2010). Formation of technological culture of a modern university lecturer. Scientific Bulletin of V.O. Sukhomlinsky. Moscow State University, 1(31), 6-10. URL: http://mdu.edu.ua/wpcontent/uploads/files/3_1.pdf

Plutok, O.V. (2020). Features of technological competence of professional training teacher

of technological profile. 132-137 [File PDF]. URL:

https://zenodo.org/record/3731240/files/Plut ok.pdf

Rean, A., \& Kolominsky, Y. (1999). Social pedagogical psychology. St. Petersburg: Piter. [In Russian]

Rokeach, M. (1973). The nature of human values. New York: Free Press.

Rubtsova, E.T. (2009). Technological culture in pedagogical education. News RGPU named after A.I. Herzen, 83, 28 - 39. [in ukrainian]

Selevko, G.K. (2005). Pedagogical technologies based on activation, intensification and effective management of OCP. Moscow: Research Institute of School Technologies. URL: http://xn--80adbhfbjjdi4ay6bo.xn-80adfztrifs.xn-p1ai/images/files/0671501_96F68_selevko_ g_k_pedagogicheskie_tehnologii_na_osnove _aktivizacii.pdf

Sysoieva, S.O. (2011). Integrative adult learning technologies. Kyiv: EKMO. [in ukrainian]

Symonenko, V.D. (2001). Technological culture and education (cultural and technological concept of society and education development). Briansk: BSPU Publishing House. $\quad$ URL: https://docplayer.com/60913918-

Simonenko-v-d-tehnologicheskaya-kulturai-obrazovanie.html

Tyshakova, L.T. (2005). Formation of technological competence of the future foreign language teacher $(\mathrm{PhD}$ in Ped. Sciences Thesis). Kramatorsk Institute of Economics and Humanities Luhansk, Kramatorsk. URL: http://www.disslib.org/formuvannjatekhnolohichnoyi-kompetentnostimajbutnoho-vchytelja-inozemnoyimovy.html

Yerastova-Mykhalus, I.B. (2016). Formation of intercultural tolerance of future masters of economics ( $\mathrm{PhD}$ in Ped. Sciences Thesis) Kirovograd State Pedagogical University named after V.Vynnychenko, Kirovograd. URL: https://inlnk.ru/emYe92 